\title{
NEW AND EVEN NEWER FOSTERING INNOVATIVENESS IN PRIMARY EDUCATION
}

\author{
Swantje Weis ${ }^{1 *}$, Claudia Scharf ${ }^{2}$, Inga Gryl ${ }^{3}$ \\ ${ }^{1}$ University of Duisburg-Essen, GERMANY, swantje.weis@uni-due.de \\ ${ }^{2}$ University of Duisburg-Essen, GERMANY, claudia.scharf@uni-due.de \\ ${ }^{3}$ University of Duisburg-Essen, GERMANY, inga.gryl@uni-due.de \\ ${ }^{*}$ Corresponding author
}

\begin{abstract}
This paper describes the need for the implementation of an education for innovativeness. Innovativeness as the ability to participate in innovation processes is a competence closely linked to participation processes in a complex, dynamic and ever-changing world that needs mature citizens to shape present and future societies in accordance with their ideas, interests, and social responsibility. This involves questioning current circumstances (reflexivity), developing new ideas (creativity) and bringing those ideas into action (implementivity), which are the three core dimensions of innovativeness. Participation options in innovation processes are multifaceted as they occur in an active, idea-creating manner, and/or in a reactive, innovationevaluating and implementing orientation as well. An education for innovativeness addresses all these extents. This paper outlines, that current educational-political documents in the case of Germany are nominally supportive towards an education for innovativeness at least by promoting the ability to participate. However, these calls do not comprehensively meet the standards of innovativeness: Firstly, because the term innovation is fuzzy and dominated by catch-word usage. Secondly, innovation and participation are mostly obligated to a neoliberalist ideal that rather supports consolidation of a given framework than mature societal changes. Widely deepening rudimentary educational-political calls for participation, this paper, in contrast, argues for a humanistic perspective on innovation processes in accordance with the humanistic ideal of education, allowing real participation as well as future- and development-oriented structuring of society. The case of the German subject Sachunterricht (Primary Social and Science Education) illustrates that innovativeness can be taught in school -even in the early years- as this interdisciplinary subject meets the open character of innovativeness and provides linkages to lifeworld related scenarios. Nevertheless, a schoolbook task analysis regarding the subject Sachunterricht reveals that there is almost no fostering of innovativeness in this given material. Space and obligation are left to develop concepts and instruments that foster innovativeness in school.
\end{abstract}

Keywords: innovativeness, innovation, participation, elementary education, Primary Social and Science Education, Sachunterricht, schoolbook analysis, task analysis

\section{LEGITIMATION-INNOVATIVENESS AS ESSENTIAL OBJECTIVE OF A HUMANISTIC EDUCATION}

Nowadays, educational goals have to be justified from a perspective, which considers the openness and uncertainty of the future in a changing world (Schnack \& Timmermann, 2008). Following this, school needs to create open learning spaces that do not only offer room to acquire defined skills and competences but 
(moreover) enable pupils to actively participate in questioning and shaping current and prospective societies (Weis, 2016). Therefore, this contribution seeks to implement innovativeness in teaching and learning arrangements as an instrument to learn and experience participation, and to gain maturity. By utilizing a concept of innovativeness, we will be able to transfer the humanistic ideal of teaching and learning as well as general educational standards to primary education practices.

For this purpose, we firstly distinguish humanism from neoliberalism in education as foundation of our thoughts. Ongoing from basic approaches and limitations of the promotion of innovativeness in educational policy (focused on the case of Germany), we will come to a more profound definition of innovativeness by merging innovation theories from various disciplinary perspectives. Following, we will analyze how school subjects such as the German subject Sachunterricht (Primary Social and Science Education)-an interdisciplinary subject from grade one to four - enable students to gain innovativeness, and subsequently investigate whether this opportunity is considered in schoolbooks for Sachunterricht.

\subsection{A changing world- Education between neoliberalism and humanism}

The current world is rapidly changing; influenced by accelerated and contradicting information and facing uncertainty about what the future holds. Furthermore, so-called innovations-promising to improve current circumstances-emerge everywhere and influence society in a complex manner. Due to this complexity, pluralism and unclear future, individuals are constantly challenged to react to (unexpected) changes (Postman \& Weingartner, 1973; Gryl, 2013). People from all ages need to develop a critical mindset in order to reflect on these dynamic changing processes, i.e. to develop the ability of (re-)acting competently, and to participate in societal decision making processes according to their very own understanding of how the world should be changed and shaped in the future (ibid.; Scharf, Schmitz \& Gryl, 2016).

However, education that leads to competences to handle the current world, can follow highly differing guidelines: I.e. the neoliberal claim of being efficient on the one hand and the humanistic ideal of literacy as a grace of humankind on the other hand. These claims form a current substantial contradiction, particularly in education. The understanding of this contrast is an important basis of the approach of innovativeness in education. Neoliberal educational settings aim at competitiveness, economic success and growth (Bellmann, 2005; Faschingeder, Leubolt, Lichtblau, Prausmüller, Schimmerl \& Striedinger, 2005). The requirement of so-called lifelong learning may serve as one concrete example of neoliberal practices. It is presented as an instrument for self-optimization, but indeed functions as a lifelong compulsion of keeping up with others (perceived as competitors) and being "fit for the job" (Tuschling, 2004, p. 157). This particular idea of learning throughout the whole life pressures people to ever improve themselves by learning societally demanded skills (Foucault, 2004; cf. Rouff, 2009; Gryl \& Naumann, 2016). People become "companies of themselves" (Rouff, 2009, p. 199, translated by the authors; Foucault, 2004; cf. Gryl \& Naumann, 2016)-within a given framework of required development. Therefore, the neoliberal aims are "truly subversive since they undermine our chances of surviving as a viable, democratic society" (Postman \& Weingartner, 1973, p. 15). In this sense of education, critical thinking is fairly possible but current systems shall not be raised to question (cf. Liessmann, 2006; Krautz, 2011; Gryl \& Naumann, 2016).

In contrast, the main goal of humanistic education is to understand the world, according to the humanistic educational ideal (Humboldt, 1792/93). Here, education is seen as a self-activity without primary valorization (Gryl \& Naumann, 2016). Nevertheless, education helps people to become aware of their own responsibility for themselves and for their environment. This responsibility enables an emancipatory attitude (Heydorn, 2004) and thereby fosters political maturity (cf. Zichy, 2010). Society does not aim at generating people who can solve known problems, but individuals who are able to identify issues, name them, and develop solutions. If the purpose of education thus is to reveal and impart societal charged relationships in terms of reflexivity (Bünger, 2009), education shall not be exploited and commercialized (Gryl \& Naumann, 2016).

Bringing together the humanistic ideal of education and the everyday scenario of a changing world, the importance of innovations and an active role in innovation processes is undoubted (Vahs \& Brem, 2015). Innovativeness-"the ability to participate in the innovation process" (Weis, 2016, p. 35, translated by the authors)-is a key for empowerment and participation according to the humanistic ideal (Weis, 2016; cf. Gryl, 2013; Jekel, Ferber \& Stuppacher, 2015; Scharf et al., 2016). This ability does not only contain the capability of yielding innovations (-active innovativeness) -but in addition the critical reaction towards what is presented as an innovation (reactive innovativeness), i.e. by society, and thus the awarding or rejecting of the seal of quality which names the novelty innovation -(Scharf et al., 2016; cf. Hartmann \& Meyer-Wölfing, 2003). Thus, this contribution will discuss in which sense current educational standards claim active and reactive innovativeness within the context of participation. 


\subsection{Participation-A starting point for innovativeness in educational policy}

As there may be various paths leading to the implementation of innovations, we consider differing approaches serving as potential starting points for innovativeness in education as well as informal learning contexts alike. Reflecting on past, current and/or forthcoming circumstances, e.g. fostered in historical learning (cf. Bernhardt et al., 2011) or in geographical learning contexts (Gryl, 2013), might give room to stimulate innovativeness in education due to the strong connection between critical thinking, reflecting and reflexivity (Carlos \& Gryl 2013) since the latter marks one of the core dimensions of innovativeness. Socalled "Spaces of the in between" (Gryl, Scharf \& Weis, in print) may also be potential informal innovativeness-fostering learning surroundings.

This contribution focuses on participation in German education as potential starting point for innovativeness as calls for participation increase (cf. KMK, 2007; Schulentwicklung NRW 2008). Besides, the example of educational policy in Germany shall illustrate how the educational system deals with challenges of a changing world. In the past, there have been multilayered changes within the educational system, especially since the publication of the results of the latest PISA report (Largo, 2013). Hence, the educational system has been subject of innovation itself. Overall, one can identify various approaches regarding content and state of implementation of reforms within the federal German education system, for instance, a wide range of concepts for all-day schools. Whereas not all agenda plans point in the same direction, there seems to be a broad-at least nominal-consensus about general educational goals: Education should not only focus on facts and specialized competencies (Klieme, Jude, Baumert \& Prenzel, 2010) but also on interdisciplinary abilities that help young learners to participate actively in their current and/or future life. Pupils need to learn to question, assess and alter their own learning processes and their whole environment alike (Weis, 2016). Aims such as these are stated out by several institutions and departments of education in Germany. For instance, the Kultusministerkonferenz (Standing Conference of the Ministers of Education and Cultural Affairs (KMK)) and the German UNESCO commission underline the importance of fostering participative performance within the 'Agenda 21', a program that focuses on participation of all societal groups in the process of sustainable development in schools (KMK, 2007). Similarly, the overall educational curricula of North Rhine-Westphalia (a German federal state), proclaims the development of pupils concerning autonomous decision making as important educational task to enable them to participate responsibly and to shape their own life (Schulentwicklung NRW, 2008, cf. MSW, 2008). Thus, pupils shall acquire the ability to act independently, to study for themselves as well as in cooperation with peers and to present their own view but also to respect the other's opinions (ibid.).

The North Rhine-Westphalian curriculum for the subject 'Sachunterricht' correlates with this claim by pointing out that pupils should learn to exploit, orient and participate responsibly (MSW, 2008). According to the Gesellschaft für Didaktik des Sachunterrichts (German Association for the Didactics of Primary Social and Science Education (GDSU)), the purpose of Sachunterricht is to support pupils "to understand their environment, to orient themselves in it and to participate and act within it" (GDSU, 2013, p. 9, translated by the authors). Sachunterricht is a particularly useful example to illustrate the interaction between educational aims and everyday life as well as further subjects, e.g. social sciences and geography for instance, since these subjects aim at enabling learners to act and participate in a changing world. In sum and in coherence with Weis (2016), it can be stated that German educational guidelines stress the importance of enabling and empowering pupils for orientation and participation as purpose and aim of education.

This overall claim for participation is again, as we have outlined above, one potential starting point for innovation, as participation is an essential aspect and aim of innovation.

\section{THEORETICAL STRUCTURE- FROM A FUZZY TERM TO A PROFOUND FRAMEWORK}

Innovation is a fuzzy, ambiguous and contextual term, used in various disciplines, and not yet (consistently) defined (Moldaschl, 2010). Furthermore, with its usage, a theoretical background is rarely provided (Nahrstedt, 1988). In order to instrumentalize innovativeness so as to extract tools for the empowerment of pupils, the term innovation needs to be sharpened (Gryl, 2013). Consequently, the following remarks lead from an analysis of the differing meanings of the term innovation to a more profound definition.

\subsection{Various disciplinary perspectives- The many faces of the innovation term}

Mainly, innovation is described from an economic perspective (Rammert, 2010), and even on a political level, the term mostly refers to economic competitiveness (acatech, 2013). Here, innovation is seen as the economic implementation of new ideas, meaning development, implementation and utilization of new approaches, processes, products or procedures that improve the (everyday) life of individuals and groups as 
well as conditions for organizations and companies (Maier, Frey, Schulz-Hardt \& Brodbeck, 2001). Following the neoliberal sense described above, innovation is an instrument for competitiveness (John, 2005) and must be predictable and plannable to meet the requirements of an economic definition (Godin, 2008; Gryl, 2013). This planning of innovations is part of the "innovation management" (cf. Braun-Thürmann, 2012). Wehle (1973) names this orientation conservative innovation (Nahrstedt, 1988; cf. Scharf et al. 2016).

From a social-scientific viewpoint, innovations are not limited to the economic sector. Moreover, innovations emerge out of society as a whole (Rammert, 2010; 2012; Nahrstedt, 1988). The focus of the social-scientific innovation research lies on the relevance of social developments in innovation processes and their influence on society (Howaldt \& Jacobsen, 2010). This includes social conditions, the interrelationship of technical and social innovation (which can be questioned, cf. Rammert, 2010), the institutional context, the interaction of participants and the organization of innovation processes (Howaldt \& Jacobsen, 2010). Besides social innovation, there are further types of innovation. Political innovation, for instance, describes the efficient manner to make politics and techniques of reigning and controlling (Rammert, 2010). Similarly, artistic innovation refers to radical changes in arts (ibid.). However, as Rammert (2010) points out, possible measurability regarding societal, economic and political questions of innovation marks a reason for the common focus on technology and economy. In an overall social-scientific sense, innovation refers to strategies that intentionally improve something in contrast to former solutions (John, 2013). When it comes to innovation as a result of an emancipatory process with a social-critical concept, Wehle (1973) names this approach progressive innovation (in contrast to the outlined conservative form of innovation) (Nahrstedt, 1988; cf. Scharf et al. 2016).

In a pedagogical context, according to Gröschner (2013, p. 306, translated by the authors), "innovation is an active process of development and change which consists of individually constructed and autonomous learning processes in a reflexive, social realm of experience". This perspective asks how pupils can learn the ability to participate in innovation processes (Gryl, 2013; Jekel et al., 2015; Scharf et al., 2016; Weis, 2016). Neuroscientific research may help to find solutions. For instance, new synapses sprout during the development of new solutions for identified problems (Holm-Hadulla, 2010). To enable this process, known schemes must be broken (Heilman, Nadeau \& Beversdorf, 2003; cf. Ritter, Damian, Simonton, van Baaren, Strick \& Derks, 2012). From a pedagogical point of view and in contrast to the economic perspective, innovation cannot be planned (Eickhorst, 1981; John, 2013; cf. Scharf et al., 2016). As Gryl (2013) and Jekel et al. (2015) point out, an innovative idea, product or process must be implemented to be deemed as such. It is the society which imparts this change and therefore marks it as an innovation (Scharf et al., 2016; cf. Rammert, 2010). This phenomenon is addressed by the idea of reactive innovation mentioned above.

\subsection{Innovativeness- Extending the idea of the ability to participate in educational settings}

Even if these approaches differ in some respects, they have in common that innovations are connoted positively and aim at improving present circumstances (Gryl, 2013; Weis, 2016). However, the positive connotation cannot be generalized as the assessment of innovation outcomes may vary depending on benefit for, and position and perspective of a single individual. Additionally, innovations may have negative side effects, such as ecological destruction (cf. Gryl, 2013). Apart from this, the innovation process is characterized by certain sub-processes that will be described in the following sections.

As the neuroscientific perspective illuminates, conversant thinking and behavior needs to be broken, in order to develop new ideas (cf. Heilman et al., 2003), i.e. to be innovative. Within this context, reflexivity, which implies questioning very own thinking and acting regarding interests and social contexts (Schneider, 2013), may function as driving force for the creation of new ideas, and subsequently for challenging and renewing current social circumstances. Therefore, Gryl (2013) identifies reflexivity as one core dimension of the innovation process.

Innovation is further driven throughout creative ideas, named inventions (cf. ibid.; Jekel et al., 2015). Therefore, creativity, a way of imaginative thinking that neither pursues certain purposes nor focuses on specific solutions (Ulmann, 1968), marks another core dimension of the innovation process (cf. Draeger, 1991; Runco, 2007).

However, inventions as results of creative processes only turn into innovations by their implementation (Maier et al., 2001; Gryl, 2013; Jekel et al., 2015). Thus, another dimension of the innovation process is the ability to implement creative ideas (ibid.). Implementivity requests being able to convince others of the existence of an issue and of implementing a proposed solution approach (ibid.). Thus, implementivity requires the assertiveness (especially when resistance appears against a developed solution) as well as good communication skills, such as convincingly presenting ideas and solution approaches to others, form 
and articulate logical arguments, and being able to competitively visualize developed solutions (cf. Budke, 2012; Weis, 2016).

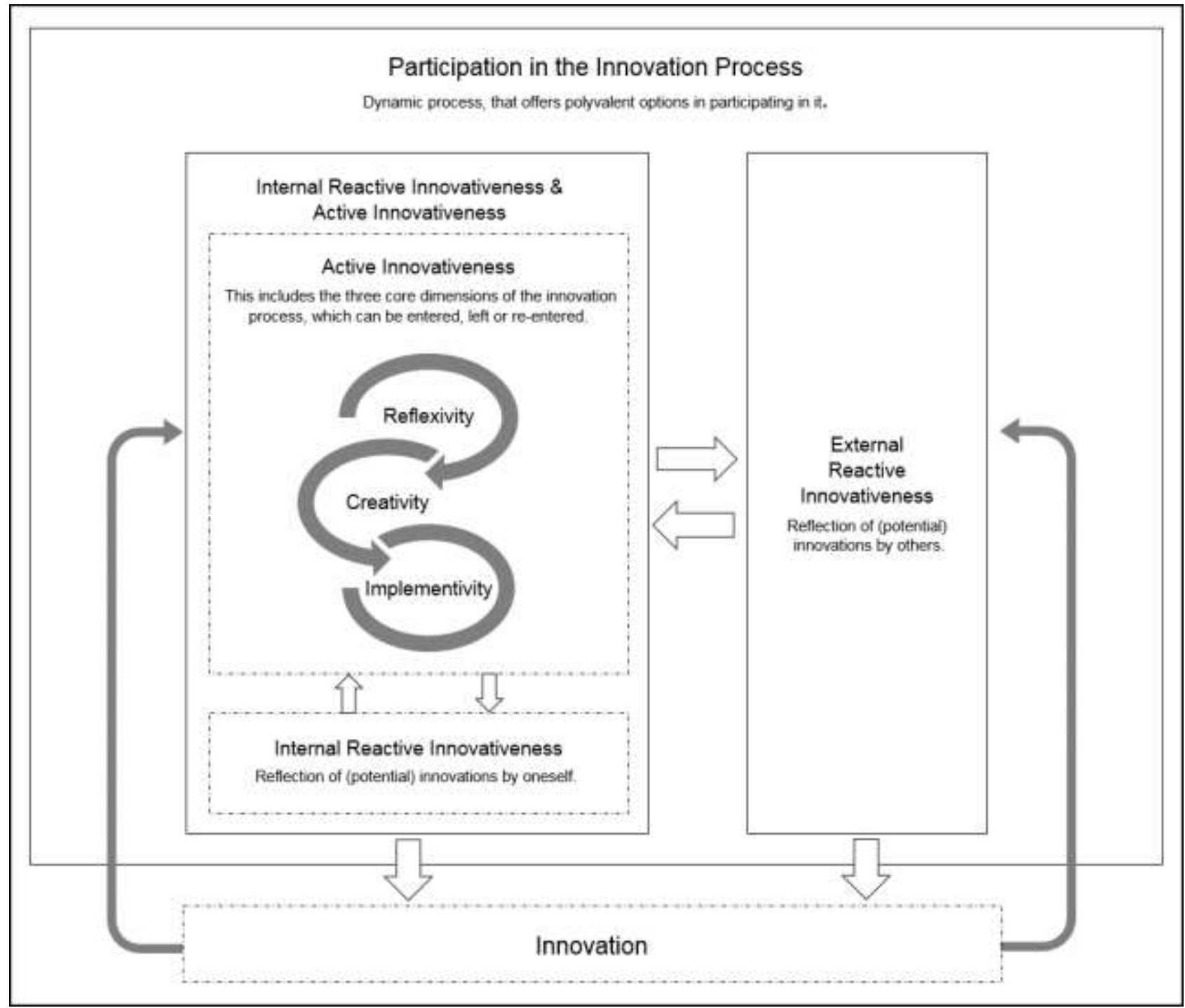

Figure 1: Participation in the innovation process (own research, based on Weis, 2016).

In conclusion, the innovation process includes the following three major dimensions (Gryl, 2013; Jekel et al., 2015): (1) Reflexivity describes the ability to question current circumstances and point out issues, whereas (2) creativity means the ability to generate creative ideas in order to find solutions for the stated issues (3) Implementivity covers the ability to convince others of the need to overcome issues through developed solutions and to put these ideas into action (ibid.).

Therefore, innovativeness as "the ability to participate in the innovation process" (Weis, 2016, p. 35, translated by the authors), includes a wide range of participation options exceeding reactive innovativeness right up to active innovativeness (Hartmann \& Meyer-Wölfing, 2003; Scharf et al., 2016). Whereas the three dimensions, reflexivity; creativity; and implementivity, form active parts of the innovation process, reactive parts include external reactive innovativeness focusing on reflections of so-called innovations by others as well as internal reactive innovativeness, that monitors own ideas as potential future or implemented innovations (Weis, 2016). Thus, both, being actively involved in the three dimensions of the innovation process and observing innovation processes from outside, can include reactive innovativeness (ibid.).

Several conceivable scenarios of the course of action and the way of participation within the innovation process can be identified. Participation in this process is open and can be entered, left and re-entered by the participants at any point. For instance, it is possible that people identify crucial issues, but do not further follow the innovation process (e.g. because they do not possess the resources needed for creativity), and cut back their participation. In such cases, the innovation process may still continue as being driven by others 
instead, who have the will and capabilities to solve this problem by generating creative solutions. Moreover, the innovation process can be deliberately interactive, e.g. when individuals, who identify problems and develop solutions, look out for external support in order to fulfill a successful implementation. Likewise, the innovation process can be interrupted (deliberately), for instance, when developed solutions for identified issues are suspended by the participants before even trying to implement them and make them future innovations due to (further) reflecting on the suitability of their solution leading to that conclusion (ibid.).

Figure 1 shows the dynamic and progressive innovation process explained above that includes potential shift in the process between the three dimensions as well as forward and backward pulses driven by reactive innovativeness. The figure therefore illustrates the polyvalent options in participating in the process.

\section{THE CASE OF PRIMARY SOCIAL AND SCIENCE EDUCATION- EXAMINATION OF INNOVATIVENESS}

Following the outlining of active and reactive innovativeness, this contribution aims at transferring the theoretical concept into practical teaching and learning arrangements. Regarding this, —next to the unceasing call for innovation (cf. Gryl, 2013) —-we identify increasing interest in implementing the learning of creativity and innovativeness in university education and professional working environments (Schubert, 2009). However, this trend does not align unreservedly with the presented concept of innovativeness, since those approaches are often driven by a normative fundament which does not aim at enabling young people to shape society and participate in it, but rather focuses on enabling workforce to fulfill (compulsory) job requirements (ibid.; Orr, 2016). In contrast, this contribution focuses on enabling people to challenge normative demands instead of learning to fulfill them, and to participate and shape society by innovativeness.

\subsection{Rationale- Reasons for innovativeness in Primary Social and Science Education}

This contribution's focus on learning innovativeness in the subject Sachunterricht has several reasons. Firstly, it aligns with the educational claims, which underline that children need to gain not only disciplinespecific competences, but also transdisciplinary abilities such as participation (GDSU, 2013; MSW, 2008). Secondly, fostering creativity, which is of high importance to the innovation process as it marks one of the three major dimensions of active innovativeness, is not an inherited ability, but instead can be acquired (Thurstone, 1962; Guilford, 1962, both cited in Ulmann, 1968). Due to the potential of creativity in childhood age (Vygotsky, 2004), this contribution seeks to foster creative thinking and acting in primary education. Furthermore, we proclaim the promotion of innovativeness within the subject Sachunterricht since it offers great potential to translate the interdisciplinary-oriented theoretical terms innovation and innovativeness into (everyday) practice. While primary school subjects usually are determined by discipline-specific knowledge, Sachunterricht is a superb example in terms of multidisciplinary teaching approaches, covering different perspectives derived from disciplines such as social sciences, geography, history, economics, and sciences. Therefore, the subject provides interdisciplinary areas of thinking and acting (Götz, Kahlert, Fölling-Albers, Hartinger, Reeken \& Wittkowske, 2015), which give room to stimulate the interdisciplinary concept of innovativeness from different angles, i.e. by linking technical and social perspectives. Finally, not only offering an interdisciplinary field to meet the concept of innovativeness, Sachunterricht moreover provides "conceptual and methodical tools" as Gryl (2013, p. 20, translated by the authors) describes it for the social and geographical perspective on the example of the analog subjects Geography as well as Geographie und Wirtschaftskunde (Geography and Economics). These tools can initiate innovativeness by revealing alternatives to current normative standards (ibid.).

Still, the concept of fostering innovativeness in Sachunterricht needs to be distinguished from existing moderate constructivist teaching concepts (Weis, 2016), such as problem-based learning and discovery learning as those approaches_-even though they challenge pupils to explore actively-leave the definition of learning outcomes to others (i.e. teachers, political norms), but not to learners themselves (cf. Neff, 1977; Foster, 1972; Liebig, 2012).

\subsection{Examination- Innovativeness by the use of schoolbook tasks?}

A first step to develop the potential to foster an education for innovativeness in Sachunterricht is the analysis of existing material used to plan and conduct this subject. The comparison of the existing praxis and the systematic theory may identify missing points in the present education and connecting points to link innovativeness-fostering instruments.

Initially, we started with an analysis of schoolbook tasks as schoolbooks represent politically defined educational goals (Weis, 2016), based on societal legitimation and schoolbook tasks in particular which are commonly defined as an important tool to ensure high standards in teaching contexts (cf. Blömeke, Risse, 
Müller, Eichler \& Schulz, 2006; Kaiser \& Albers, 2010; Kiper, 2010). At the same time schoolbook tasks function as an efficient teaching tool for classroom management (Thonhauser, 1995).

For the analysis, the characteristics of schoolbook tasks for Sachunterricht, based on theoretical work by Ralle, Prediger, Hammann and Rothgangel (2014), were extracted. This strategy allows a comprehensive and broad categorization of authentic tasks (Weis, 2016). Thereupon, a category system-derived from conceptual work by Büchter and Leuders (2005) and enriched by viewing authentic schoolbook tasks of Sachunterricht as well as by having a closer look at didactical framework regarding political objectives for (schoolbook) tasks for the subject (cf. GDSU, 2013; MSW, 2008)-was developed, with respect to the theoretical background of innovativeness. Following, the developed category system was applied to the commonly used schoolbook for Sachunterricht in North Rhine-Westphalia "Pusteblume" (Kraft, 2014). This book is empirically proofed the most used one for this subject within the city Essen, Germany (Weis, 2016).

Within the developed category system, twelve task groups -which are constituted based on fostering student activities belonging to the similar field of action-can be identified, e.g. "replication", "experimenting", "communicating", "systematization" or "innovating actively" (Weis, 2016, p.45ff, translated by the authors). Each of these twelve task group captures in total 35 different task types (ibid.). For instance, among the task group "systematization", the six task types (1) "questioning \& hypothesizing", (2) "describing", (3) "characterizing", (4) "comparing", (5) "determining correlations" as well as (6) "reflecting results" are summed up (ibid). The task group "innovating actively" captures (1) "identifying issues", (2) "developing creative solutions" and (3) "implementing solutions" (ibid.). Any task within the analyzed schoolbook match any of the task types within this group which leads to the conclusion that innovativeness is not directly fostered. Therefore, a closer look at indirect connections is considered: the category system does not only record task types, which are directly connected to innovativeness, but provides furthermore linkages to the three major constituting dimensions of innovativeness, based on the theoretical framework outlined above. Within the group "systematization" for instance, especially the task type "reflecting results" (ibid.) is closely linked to innovativeness since internal reactive innovativeness requests reflecting on potential innovations by oneself and thereby aligns with reflecting on solutions in general as the example task "Compare your collection of ideas with the ideas your classmates elaborated" (Kraft, 2014, p. 20, translated by the authors) illustrates. The task type "argumentation" belonging to the task group "communication" (Weis, 20116; p. 45ff, translated by the authors), forms another example of tasks that can be linked to innovativeness indirectly since the ability to implement potential innovations requires strong argumentation skills to convince others from the developed solution approach and can therefore be related to the dimension implementivity. However, only the task "Reason why the choices you made are suitable excursion destinations for your class" (Kraft, 2014, p. 159 , translated by the authors), belong to this task type, can be identified.

The findings reveal that usual schoolbook tasks for Sachunterricht hardly either initiate learning of innovativeness directly or foster innovativeness through tasks which can be linked to the three major dimensions of innovativeness as the examples mentioned above illustrate. Among 495 analyzed tasks, only seven invite pupils to reflect on results, whereas only one task fosters argumentation skill as outlined above. Instead, closed task types (cf. Büchter \& Leuders, 2005) with specified action and response options are dominant, which may be attributed to very basic competence development in accordance with a neoliberal education praxis. For instance, even within the task group "creative work" (Weis, 2016, p. 45ff, translated by the authors) which includes task types that foster activities such as building models and visualizing ideas, are only tasks that are completely guided and bossed since they specify exactly what and how to do it. No tasks could be identified that offer open space for children to present their very own ideas in a creative way. The schoolbook tasks in general show a similar pattern since for the task types "experimentation" (ibid.) as well as "observing" (ibid.) no open tasks can be identified. Only within the field of the task types "gathering information" (ibid.), a few open tasks are determined. Still, the majority are closed task (ibid.).

Overall, only within the task groups "systematization," activities are given that can be linked to the three dimensions of innovativeness. 36 tasks can be identified, that foster raising questions or framing hypothesisfor instance, formulating hypothesis on the outcome of experiments, as well as at least 23 tasks, which focus on comparing certain circumstances such as contrasting historical to current documents. However, compared to the domination of closed task types, these few examples only spot a small segment of tasks that can be associated with fostering innovativeness (Weis, 2016).

In conclusion, Weis' (2016) category system has proven as a valid measuring instrument and will be used for the evaluation of further teaching material, e.g. worksheets which are online available and besides schoolbooks widely used by teachers as her survey has revealed for Essen. Furthermore, the category system is a fruitful basis for the development of innovativeness-fostering material, paying attention to the different dimensions and the basic competences needed to constitute innovativeness for a systematic built- 
up of innovativeness among young learners.

\section{CONCLUSION AND OUTLOOK- TOWARDS AN IMPLEMENTATION OF INNOVATIVENESS IN PRIMARY EDUCATION}

This paper has shown how educational objectives and societal need for participation can be answered by innovativeness as the ability to participate in innovation processes that challenge social conditions and improve societies in accordance with subjective ideas and social responsibility. Despite the common call for innovations throughout many fields of society and curriculums with a decidedly alignment for participationas the German case has proven, innovativeness is far from being part of regular education, as Weis' (2016) schoolbook analysis has shown for the case of the particularly appropriate subject 'Sachunterricht.' Rather, teaching innovativeness which does not follow the idea of qualifying for a workforce and being capable to innovate only for economic sake, but based on a humanistic ideal of education involving maturity, is a desideratum.

Innovativeness, including the dimensions reflexivity, creativity, and implementivity; and approaches innovation processes in an active and in a reactive manner alike, is a complex competence to teach and learn, but at the same time an inevitable basis for the prospective constitution of society. For this, several didactical instruments have to be identified (Scharf et al., under review; Scharf, forthcoming) and developed (Weis et al., 2017; Weis, forthcoming) which prepare learners for participation in innovation processes, according to the developed category system, e.g. open-ended tasks, stimuli to change perspective and practice of negotiation. This also requires an innovation-friendly classroom that bethinks of its humanistic background beyond a praxis of seemingly-humanistic catchwords dominated by a neoliberal praxis. Further examination has to be conducted to reveal the existing praxis or non-praxis towards innovation in school besides the orientation on-innovativeness-inadequate-schoolbooks. When implementing the innovativenesspromoting instruments, systematic evaluation for their outcomes is needed.

The subject Sachunterricht is the first choice when teaching innovativeness, due to its interdisciplinary, everyday references, and early start in the education system. Besides, participation and innovation issues are neither limited to the subject Sachunterricht nor to primary education. As several other school subjects emphasize the importance of participation and the purpose of fostering it, the consolidation of the ability to participate-innovativeness-has to be supported within these subjects as well.

\section{REFERENCE LIST}

acatech (Deutsche Akademie der Technikwissenschaften) (2013). Innovationsdialog zwischen

Bundesregierung, Wirtschaft und Wissenschaft. Available at

http://innovationsdialog.acatech.de/organisation.html. Accessed 30 December 2016.

Bellmann, J. (2005). Ökonomische Dimensionen der Bildungsreform. Neue Sammlung, 45 (1).

Bernhardt, M., Gautschi, P. \& Mayer, U. (2011): Historisches Lernen angesichts neuer Kerncurricula. Wiesbaden: Hessisches Kultusministerium. Available at http://www.phlu.ch/fileadmin/media/phlu.ch/fe/zge/Bernhardt_Markus_Gautschi_Peter_Mayer_U Irich_2011_.Historisches_Lernen_angesichts_neuer_Kerncurricula.pdf. Accessed 01 July 2017.

Blömeke, S., Risse, J., Müller, C., Eichler, D. \& Schulz, W. (2006). Analyse der Qualität von Aufgaben aus didaktischer und fachlicher Sicht. Unterrichtswissenschaft. Zeitschrift für Lernforschung, 34 (4).

Büchter, A. \& Leuders, T. (2005): Appropriate problems for learning and for performing_an issue for teacher training. ZDM, 37 (5).

Büchter, A. \& Leuders, T. (2005). Mathematikaufgaben selber entwickeln. Berlin: Cornelsen.

Budke, A. (2012). Argumentationen im Geographieunterricht. Geographie und ihre Didaktik, 40 (1).

Bünger, C. (2009). Emanzipation im Widerspruch. In C. Bünger et al. (eds.), Heydorn lesen! (pp. 171-192). Paderborn: Ferdinand Schöningh.

Carlos, V. \& Gryl, I. (2013). Where do Critical Thinking and Spatial Citizenship meet? Proposing a framework of intersections. In Jekel, T., Car, A., Strobl, J. \& Griesebner, G. (eds.), GI_Forum (pp. 437-446), 
Berlin: Wichmann.

Draeger, W. (1991). Innovation-Invention-Kreativität. Düsseldorf: VDI-Verl.

Eickhorst, A. (1981). Innovation im Unterricht. München: Minerva.

Faschingeder, G., Leubolt, B., Lichtblau, P., Prausmüller, O., Schimmerl, J. \& Striedinger, A. (2005). Bildung ermächtigt. In Österreichische HochschülerInnenschaft, Paulo Freire Zentrum (ed.), Ökonomisierung der Bildung (pp. 7-25). Wien: Mandelbaum.

Foster, J. (1972). Discovery Learning in the Primary School. London: Routledge and K. Paul.

Foucault, M. (2004). Geschichte der Gouvernementalität II. FFM: Suhrkamp.

GDSU (Gesellschaft für Didaktik des Sachunterrichts) (ed.) (2013). Perspektivrahmen Sachunterricht. Regensburg: Klinkhardt.

Götz, M., Kahlert, J., Fölling-Albers, J., Hartinger, A., Reeken, D. v. \& Wittowske, S. (2015). Didaktik des Sachunterrichts als bildungswissenschaftliche Disziplin (pp. 27-30). In J. Kahlert et al. (eds.), Handbuch Didaktik des Sachunterrichts. Bad Heilbrunn: Klinkhardt.

Gröschner, A. (2013). Innovationskompetenz als Element der Lehrerausbildung. In: M. Rürup \& I. Borman (eds.), Innovationen im Bildungswesen (pp. 303-328). Wiesbaden: Springer VS.

Gryl, I \& Naumann, J. (2016). Mündigkeit im Zeitalter des ökonomischen Selbst? GW-Unterricht, 141 (1).

Gryl, I. (2013). Alles neu. GW-Unterricht, 131.

Gryl, I., Scharf, I. \& Weis, S. (in print): Geomedia and the spaces of the in between. GI_Forum, 2.

Hartmann, T \& Meyer-Wölfing, E. (2003). Nutzung von Innovationspotentialen in außerbetrieblichen Handlungs- und Lernfeldern. QUEM-Report, 83.

Heilman, K. M., Nadeau, S. E. \& Beversdorf, D. O. (2003). Creative innovation. Neurocase, 9.

Heydorn, H.-J. (2004). Über den Widerspruch von Bildung und Herrschaft. In I. Heydorn et al. (eds.), Werke in neun Bänden. Wetzlar: Pandora.

Holm-Hadulla, R. M. (2010). Kreativität zwischen Frust und Flow. In R. Rosenzweig (ed.), Geistesblitz und Neuronendonner (pp. 45-60). Paderborn: Mentis.

Howaldt, J. \& Jacobsen, H. (2010). Soziale Innovation. In J. Howaldt \& H. Jacobsen (eds.), Soziale Innovation (pp. 9-18). Wiesbaden: Springer VS.

Humboldt, W. v. (1792/93). Theorie der Bildung des Menschen (Bruchstück). In A. Filtner \& K. Giel (eds.) (1969), Wilhelm von Humboldt (pp. 234-240). Darmstadt: Wissenschaftliche Buchgesellschaft.

Jekel, T., Ferber, N. \& Stuppacher, K. (2015). Innovation vs. innovativeness. GI_Forum, 3.

John, R. (2005). Innovationen als irritierende Neuheiten. In J. Aderhold \& R. John (eds.), Innovation (pp. 4964). Konstanz: UVK.

John, R. (2013). Innovation als soziales Phänomen. In M. Rürup \& I. Borman (eds.), Innovationen im Bildungswesen (pp. 71-88). Wiesbaden: Springer VS.

Kaiser, A. \& Albers, S. (2010). Kompetenzförderung im Sachunterricht durch Schulbuchaufgaben? In H. Kiper et al. (eds.), Lernaufgaben und Lernmaterialien im kompetenzorientierten Unterricht (pp. 188197). Stuttgart: Kohlhammer.

Kiper, H. (2010). Der systematische Ort von Aufgaben in Theorie des Unterrichts. In H. Kiper et al. (eds.), Lernaufgaben und Lernmaterialien im kompetenzorientierten Unterricht (pp. 44-59). Stuttgart: Kohlhammer.

Klieme, E., Jude, N., Baumert J. \& Prenzel, M. (eds.) (2010). PISA 2009. Münster: Waxmann.

KMK (Kultusministerkonferenz) (ed.) (2007). Available at http://www.kmk.org/fileadmin/Dateien/ veroeffentlichungen_beschluesse/2007/2007_06_15_Bildung_f_nachh_Entwicklung.pdf. Accessed 28 December 2016.

Kraft, D. (ed.) (2014). Pusteblume. Das Arbeitsbuch 3 und 4. Braunschweig: Schroedel.

Krautz, J. (2011). Ware Bildung. München: Diederichs. 
Largo, R. H. (2013). Wer bestimmt den Lernerfolg. Weinheim \& Basel: Beltz.

Liebig, S. (ed.) (2012). Entdeckendes Lernen. Baltmannsweiler: Schneider Verlag Hohengehren.

Liessmann, K. (2006). Theorie der Unbildung. Wien: Paul Zsolnay.

Maier, G. W., Frey, D., Schulz-Hardt, S. \& Brodbeck, F. C. (2001). Innovation. In G. Wenninger (ed.), Lexikon der Psychologie (pp. 264-267). FFM: Spektrum.

Moldaschl, M. (2010). Innovation in sozialwissenschaftlichen Theorien. BWL, IX (8).

MSW (Ministerium für Schule und Weiterbildung des Landes Nordrhein-Westfalen) (ed.) (2008). Richtlinien und Lehrpläne für die Grundschule in Nordrhein-Westfalen. Frechen: Ritterbach.

Nahrstedt, W. (1988). Freizeitpädagogik, Kulturarbeit und Tourismus als Innovationsbereich. In V. Buddrus, H. Sünker \& H. Zygowski (eds.), Die Zukunft pädagogisch gestalten (pp. 59-86). Bielefeld: Pfeffer.

Neff, G. (ed.) (1977). Praxis entdeckenden Lernens in der Grundschule. Kroneberg: Ts.

Orr, D. (2016). Digitalisierung und Lernen. Syergie, 2.

Postman, N. \& Weingartner, C. (1973). Teaching as a subversive activity. New York: Delocate.

Ralle, B., Prediger, S., Hammann, M. \& Rothgangel, M. (2014). Einleitung. In B. Ralle et al. (eds.), Lernaufgaben entwickeln, bearbeiten und überprüfen (pp. 9-11). Münster: Waxmann.

Rammert, W. (2010). Die Innovationen der Gesellschaft. In J. Howaldt \& H. Jacobsen (eds.), Soziale Innovation (pp. 21-51). Wiesbaden: Springer VS.

Rammert, W. (2012). Vielfalt der Innovation und gesellschaftlicher Zusammenhalt. In M. Löw (ed.), Vielfalt und Zusammenhalt (pp. 619-640). FFM: Campus Verlag.

Ritter, S. M, Damian, R. I, Simonton, D. K., v. Baaren, R. B., Strick, M., Derks, J. \& Dijksterhuis, A. (2012). Diversifying experiences enhance cognitive flexibility. Journal of Experimental Social Psychology, 48.

Rouff, M. (2009). Foucault-Lexikon, Paderborn: Wilhelm Fink/UTB.

Runco, M.A. (2007). Creativity. Amsterdam: Elsevier.

Scharf, C., Schmitz, S. \& Gryl, I. (2016). Innovativeness as fresh ground. Gl-Forum, 1. Available at. http://hw.oeaw.ac.at/?arp=0x0034005c. Accessed 30 December 2016.

Scharf, C., Gryl, I. \& Weis, S. (under review): Innovative Pupils! Documentary Research on Teaching and Learning Arrangements for Innovativeness. The European Conference of Education (ECE).

Scharf, C. (forthcoming). Dissertation project. Essen.

Schnack, J. \& Timmermann, U. (2008). Kernkompetenz Selbstständigkeit: Was junge Menschen heute lernen müssen. Pädagogik, 9 (60).

Schneider, A. (2013). Geographiedidaktische Reflexivität. Berlin: LIT Verlag.

Schubert, T. (2009). Kreativität und Innovation. BWP, 6.

Schulentwicklung NRW (2008). Richtlinien und Lehrpläne für die Grundschule in Nordrhein-Westfalen. Available at https://www.schulentwicklung.nrw.de/lehrplaene/upload/klp_gs/LP_GS_2008.pdf. Accessed 28 December 2016.

Thonhauser, J. (1995). Das Schulbuch im Spannungsfeld zwischen Wissenschaft und Ideologie. In R. Olechowski (ed.), Schulbuchforschung (pp. 175-194). FFM: Peter Lang.

Tuschling, A. (2004). Lebenslanges Lernen. In Bröckling, U. \& Krasmann, L. (eds.). Glossar der Gegenwart (pp. 152-158). Berlin: Suhrkamp.

Ulmann, G. (1968). Kreativität. Basel: Julius Beltz.

Vahs, D. \& Brem, A. (2015). Innovationsmanagement. Stuttgart: Schäffer-Poeschel.

Vygotsky, L. S. (2004). Imagination and creativity in childhood. Journal of Russian and East European Psychology, 42 (1).

Wehle, G. (1973). Pädagogik aktuell. München: Kösel.

Weis, S. (2016). Schüler als Entdecker, Erfinder, Erneuerer? Unpublished examination paper. Essen. 
Weis, S., Scharf, C., Greifzu, L. \& Gryl, I. (2017). Stimulating by simulating. Fostering innovativeness in education. IACB, ICE \& ICTB: Conference Proceedings. Available at https://www.cluteinstitute.com/conference-proceedings/sh17proceedings.pdf. Accessed 11 July 2017.

Weis, S. (forthcoming). Dissertation project. Essen.

Zichy, M. (2010). Das humanistische Bildungsideal. In M. Schmidhuber (ed.), Formen der Bildung (pp. 9-42). FFM: Peter Lang. 